\title{
The Numismatic Production of Antiochos IV: TOOL OF Diplomacy or Legitimacy? A Quantifying Approach of Hoard Evidence
}

\author{
Panagiotis P. Iossif" \\ Belgian School at Athens, Radboud University Nijmegen
}

\begin{abstract}
This article proposes a quantitative reading of the hoard evidence concerning the coin production of Antiochos IV. The "Seleucid Hoard Database" (SHD) is used as the starting point for addressing the question of coinage as "tool of diplomacy or legitimacy" of the king's reign. The demonstration, following a recent comparable analysis on the coinage of Antiochos III, is meant to serve as a methodological manifest of the usefulness of large datasets, statistical analyses and quantifications when considering historical issues. The role of Antioch as a major mint is examined, as well as the westward circulation patterns of Antiochos' issues, while the quantitative analysis of obverse and reverse types serves as a reference point for the divinization of the king and the political messages transmitted through his numismatic production.
\end{abstract}

Key words: Antiochos IV, Divinization, Political messages, Antioch, Quantification, Statistical analyses.

\section{Introduction}

Antiochos IV Epiphanes, the "Epimanes" of Polybios, remains even today one of the most intriguing and fascinating figures in Hellenistic history. ${ }^{1}$ Following a series of "romanesque" adventures which led him to Republican Rome as a hostage fulfilling one of the clauses of the Treaty of Apamea ${ }^{2}$ and then to Athens where he made his presence felt by a series of donations and benefactions, ${ }^{3}$ Antiochos IV claimed his ancestral rights to the throne using the military and financial contribution of Eumenes II of Pergamon; ${ }^{4}$ by

${ }^{*}$ I would like to thank the following colleagues for discussions on different aspects considered in this paper: Alain Bresson, Omar Coloru, Catharine Lorber, Petr Veselý, Jan Moens, Banban Wang, and Bradley Bowlin (also for improving the English text). All dates are BC; all possible errors of interpretation are, of course, my own.

1 See Mittag 2006, 18-48 for the most recent analysis of the king's policy (with previous bibliography).

2 App. Syr. 39.

3 App. Syr. 45.

4 I.Perg. 160B. 
175, he became king associating his nephew (Antiochos the Son) to the throne before eliminating him and becoming sole king. It is difficult to judge Antiochos' qualities as king since ancient sources were particularly hostile to Epiphanes, with his contemporary Polybios leading the attacks. ${ }^{5}$

From a numismatic point of view, his reign was often considered especially by leading numismatists like Otto Mørkholm and Georges Le Rider. ${ }^{6}$ Nevertheless, these studies never attempted to propose a detailed analysis of his coinage(s) from a quantitative point of view. In what follows, I will try to discuss Antiochos' monetary production based on the following numismatic dataset the "Seleucid Hoards Database" (hereafter: SHD) containing all hoards with, at least, one Seleucid coin. The purpose of the present paper is to address questions of Seleucid numismatics and explore, if coinage as observed through a detailed analysis of the hoard data, was used as a tool for diplomacy and/or legitimization by Antiochos IV Epiphanes. Some interesting facts observed through the initial analysis of the two datasets will be presented showing that quantification is a key factor for understanding the policy of a king from a numismatic point of view.

\section{Short presentation of the databases}

Two large databases were the subject of a series of recent articles. In a 2015 article, I insisted on their reliability using a series of statistical tests; the conclusion was that both the SHD and SED (Seleucid Excavations Database) can be (and should be) used as reliable starting points for the quantitative analysis of any Seleucid numismatic analysis.? The SHD and the SED were built with the intention to facilitate quantifications of different aspects varying from the most prolific mints of a given reign to the most represented deity under another reign. Since the detailed analysis of the above mentioned databases appeared in recent publications, I can only refer to them without entering here a discussion on their reliability, their modus operandi or their usefulness. I will simply sum up the numerical data from the two datasets in the table 1 as reminders of the general numbers considered in the present analysis.

Table 1. Summary statistics for SHD and SED

\begin{tabular}{|c|c|c|c|c|c|c|c|c|}
\hline $\begin{array}{c}\text { Data- } \\
\text { base }\end{array}$ & $\begin{array}{c}\text { Hoards/ } \\
\text { Sites }\end{array}$ & $\begin{array}{c}\text { No. of } \\
\text { Parameters }\end{array}$ & $\begin{array}{c}\text { Tetra- } \\
\text { drachms }\end{array}$ & $\begin{array}{c}\text { Silver } \\
\text { Fractions }\end{array}$ & AEs & $\begin{array}{c}\text { Total } \\
\text { coins }\end{array}$ & $\begin{array}{c}\text { 'SHD tetra } \\
\text { value'/ } \\
\text { 'SED C } \\
\text { bronze } \\
\text { value' }\end{array}$ & $\begin{array}{c}\text { 'SHD tetra } \\
\text { value' } \\
\text { 'SED E } \\
\text { bronze } \\
\text { value'* }\end{array}$ \\
\hline SHD & 253 & 41 & 10,230 & 826 & 1,549 & 12,605 & 10,437 & 10,437 \\
\hline SED & 80 & $\mathbf{3 8}$ & 24 & 29 & $\mathbf{6 , 3 2 0}$ & $\mathbf{6 , 3 9 9}$ & $\mathbf{5 , 9 8 9 . 5}$ & $\mathbf{2 3 , 9 1 6}$ \\
\hline
\end{tabular}

* For the definition of 'SHD tetra value'/'SED C bronze value' and 'SHD tetra value'/'SED E bronze value', see Iossif 2016, 268-269.

\footnotetext{
${ }^{5}$ Mittag 2006, 18-31 and passim for an analysis of the sources.

${ }^{6}$ Mørkholm 1963, 1965/1966; Le Rider 1999, 190-233.

${ }^{7}$ Iossif 2011a, 2014, 2015, 2016, 2017.
} 


\section{Hoard evidence (SHD) for Antiochos IV}

As has already been done recently in the case of Antiochos III, the data for Antiochos IV in SHD can be considered in two ways: either by focusing on the coins produced by Antiochos IV or by considering those coins buried during his reign. ${ }^{8}$ The former allows for access to the numismatic production of the king while the later offers a snapshot of the circulation patterns during his reign covering the decades from 180-171 to 170-161 in SHD. In this paper and for the purpose of the analysis, we will focus on the coinage produced by Antiochos IV Epiphanes, its circulation patterns, the quantifying data we can get, and conclusions related to his policy towards other states and/or his subjects.

As already described in table 1, 10,230 tetradrachms were recorded. Of these, only 405 (i.e. $4.8 \%$ ) are produced bearing the name of Antiochos IV. As can be seen in table 2 below, the precious metal issues of the king are not the most numerous in the dataset occupying only the ninth position and a small percentage of the total mostly dominated by late Seleucid issues. ${ }^{9}$

Table 2. Number of tetradrachms of Antiochos IV in SHD expressed as row numbers and percentage

\begin{tabular}{|c|c|c|c|}
\hline Order & Reign & \# of Tetradrachms & \% of Tetradrachms \\
\hline 1 & Antiochos VII & 2023 & $19.8 \%$ \\
\hline 2 & Demetrios II & 1716 & $16.8 \%$ \\
\hline 3 & Antiochos II & 691 & $6.8 \%$ \\
\hline 4 & Demetrios I & 688 & $6.7 \%$ \\
\hline 5 & Seleucos I & 663 & $6.5 \%$ \\
\hline 6 & Seleucos II & 643 & $6.3 \%$ \\
\hline 7 & Antiochos I & 506 & $4.9 \%$ \\
\hline 8 & Alexander I Balas & 499 & $4.9 \%$ \\
\hline 9 & Antiochos III & 495 & $4.8 \%$ \\
\hline 10 & Antiochos VIII & 492 & $4.8 \%$ \\
\hline 11 & Philip I & 432 & $4.2 \%$ \\
\hline $\mathbf{1 2}$ & Antiochos IV & $\mathbf{4 0 5}$ & $\mathbf{3 . 9 \%}$ \\
\hline & Total & $\mathbf{1 0 2 3 0}$ & \\
\hline
\end{tabular}

Table 3 proposes the same analysis for the silver fractions in SHD. Contrary to what has been observed for Antiochos III, ${ }^{10}$ Epiphanes' smaller silver denominations (mostly drachms) represent a much higher percentage of the total with $16 \%$ of all issues in SHD, the second highest percentage among all Seleucid issues and almost four times higher than that of tetradrachms.

${ }^{8}$ Iossif 2017.

9 For practical reasons, tables 2 to 4 illustrate the data for the twelve most represented issues. This explains the difference between totals as expressed in the bottom row and those of the above represented issues.

${ }^{10}$ Iossif 2017, 45-46. 


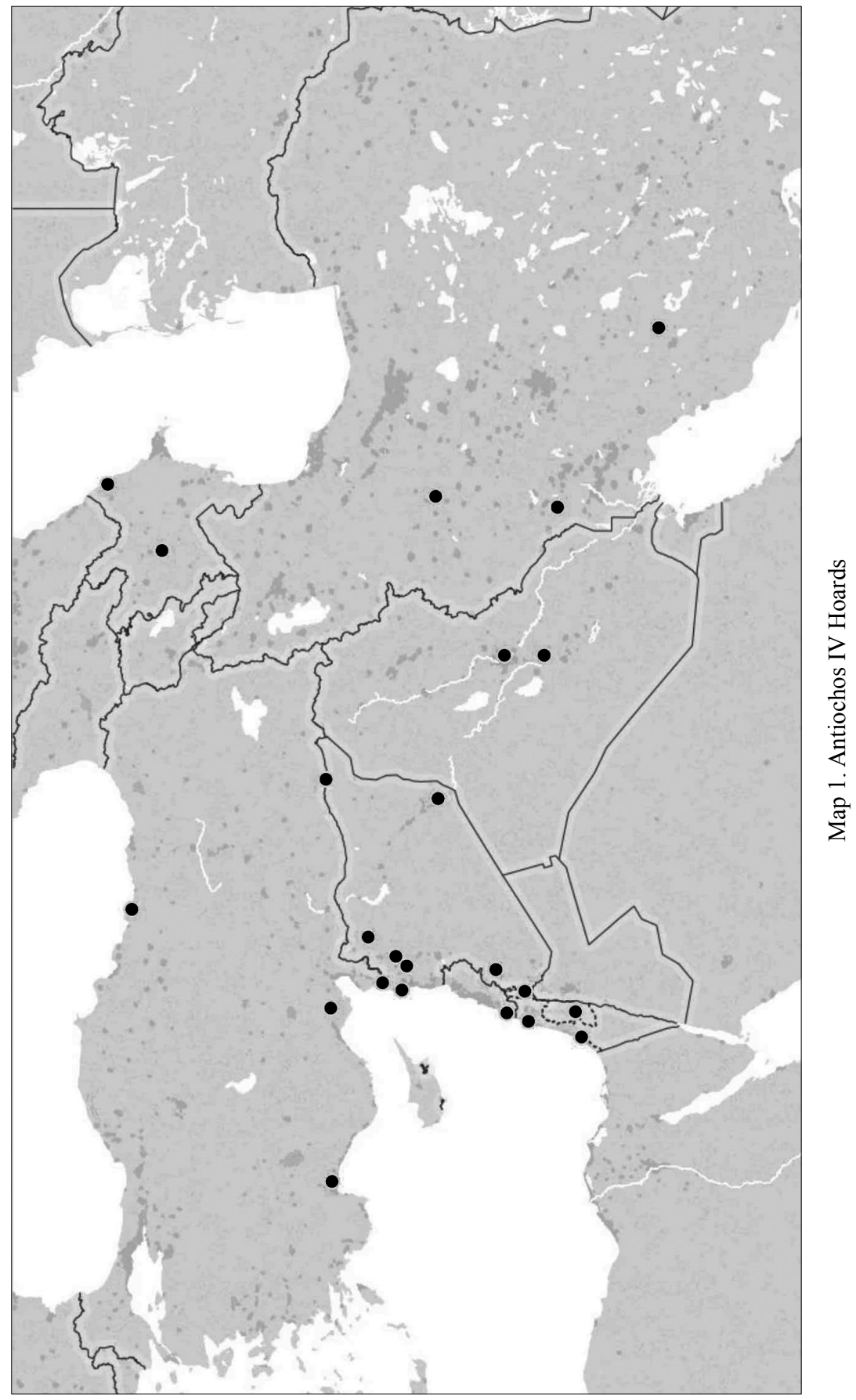


Table 3. Number of silver fractions of Antiochos IV in SHD expressed as row numbers and percentage

\begin{tabular}{|c|c|c|c|}
\hline Order & Reign & \# of Silver Fractions & \% of Silver Fractions \\
\hline 1 & Demetrios I & 212 & $25.5 \%$ \\
\hline $\mathbf{2}$ & Antiochos IV & $\mathbf{1 3 3}$ & $\mathbf{1 6 . 0 \%}$ \\
\hline 3 & Seleucos I & 96 & $11.6 \%$ \\
\hline 4 & Antiochos VII & 75 & $9.0 \%$ \\
\hline 5 & Seleucos II & 64 & $7.7 \%$ \\
\hline 6 & Alexander I Balas & 57 & $6.9 \%$ \\
\hline 7 & Seleucos IV & 39 & $4.7 \%$ \\
\hline 8 & Antiochos III & 39 & $4.7 \%$ \\
\hline 9 & Antiochos I & 34 & $4.1 \%$ \\
\hline 10 & Demetrios II & 29 & $3.5 \%$ \\
\hline 11 & Antiochos II & 21 & $2.5 \%$ \\
\hline 12 & Alexander II Zabinas & 9 & $1.1 \%$ \\
\hline & Total & $\mathbf{8 2 6}$ & \\
\hline
\end{tabular}

In table 4 are summarized the data for bronze issues as recorded in the hoard database. Here, the image follows that of silver fractions, since the coins produced under Antiochos IV represent c. $19 \%$ of the total.

Table 4. Number of bronzes of Antiochos IV in SHD expressed as row numbers and percentage

\begin{tabular}{|c|c|c|c|}
\hline Order & Reign & \# of AEs & \% of AEs \\
\hline 1 & Antiochos II & 314 & $20.3 \%$ \\
\hline 2 & Antiochos III & 306 & $19.8 \%$ \\
\hline $\mathbf{3}$ & Antiochos IV & $\mathbf{2 8 7}$ & $\mathbf{1 8 . 5 \%}$ \\
\hline 4 & Demetrios III & 104 & $6.7 \%$ \\
\hline 5 & Antiochos VIII & 95 & $6.1 \%$ \\
\hline 6 & Demetrios I & 69 & $4.5 \%$ \\
\hline 7 & Demetrios II & 59 & $3.8 \%$ \\
\hline 8 & Antiochos XII & 54 & $3.5 \%$ \\
\hline 9 & Seleucos I & 45 & $2.9 \%$ \\
\hline 10 & Antiochos IX & 41 & $2.6 \%$ \\
\hline 11 & Antiochos VII & 37 & $2.4 \%$ \\
\hline 12 & Antiochos I & 27 & $1.7 \%$ \\
\hline & Total & $\mathbf{1 5 4 9}$ & \\
\hline
\end{tabular}

From the 253 hoards in SHD, 41 hoards (16\%) contain coins of Antiochos IV. Of these, 26 hoards contain tetradrachms (map 2), nine silver fractions (map 3), and ten bronze coins (map 4). 


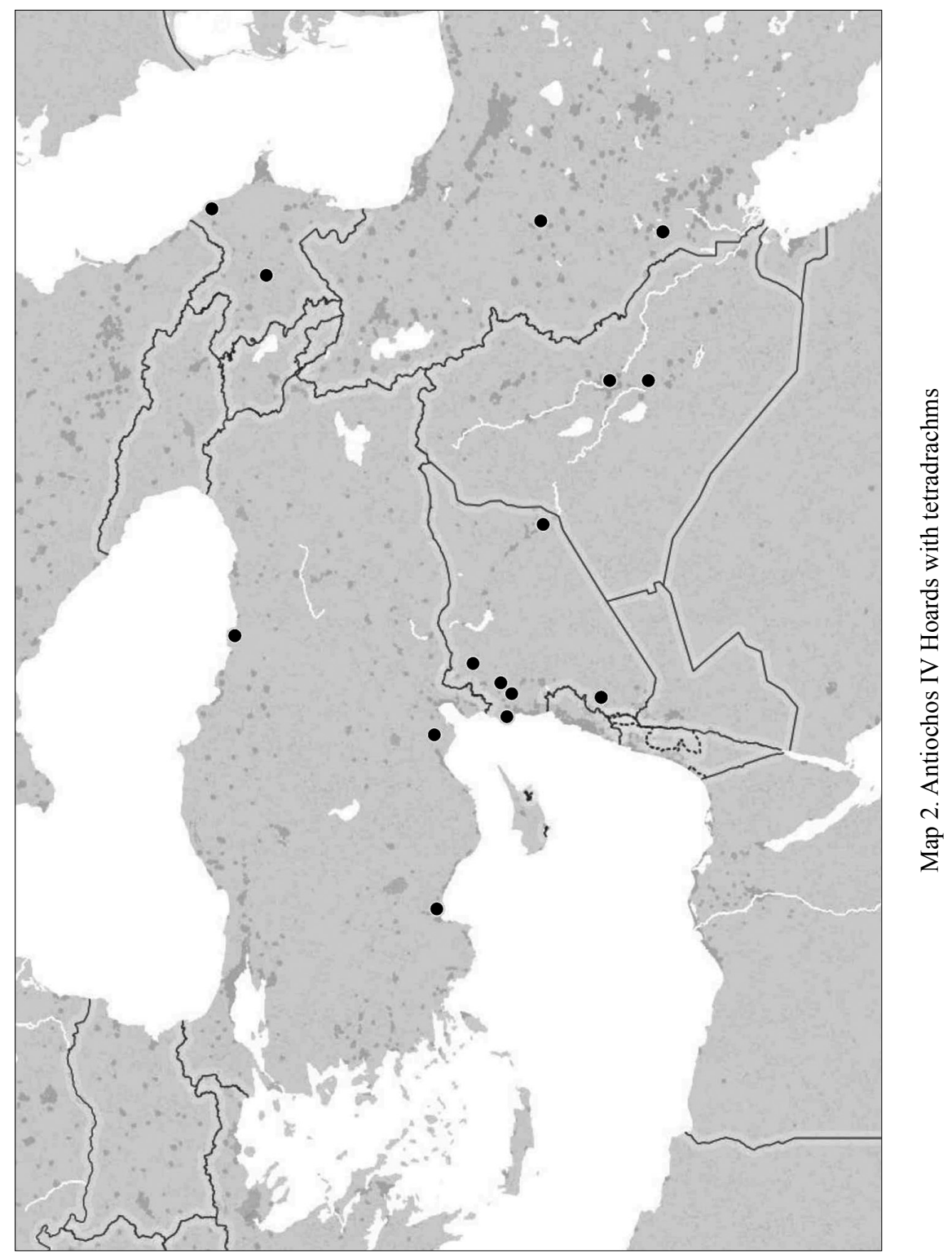




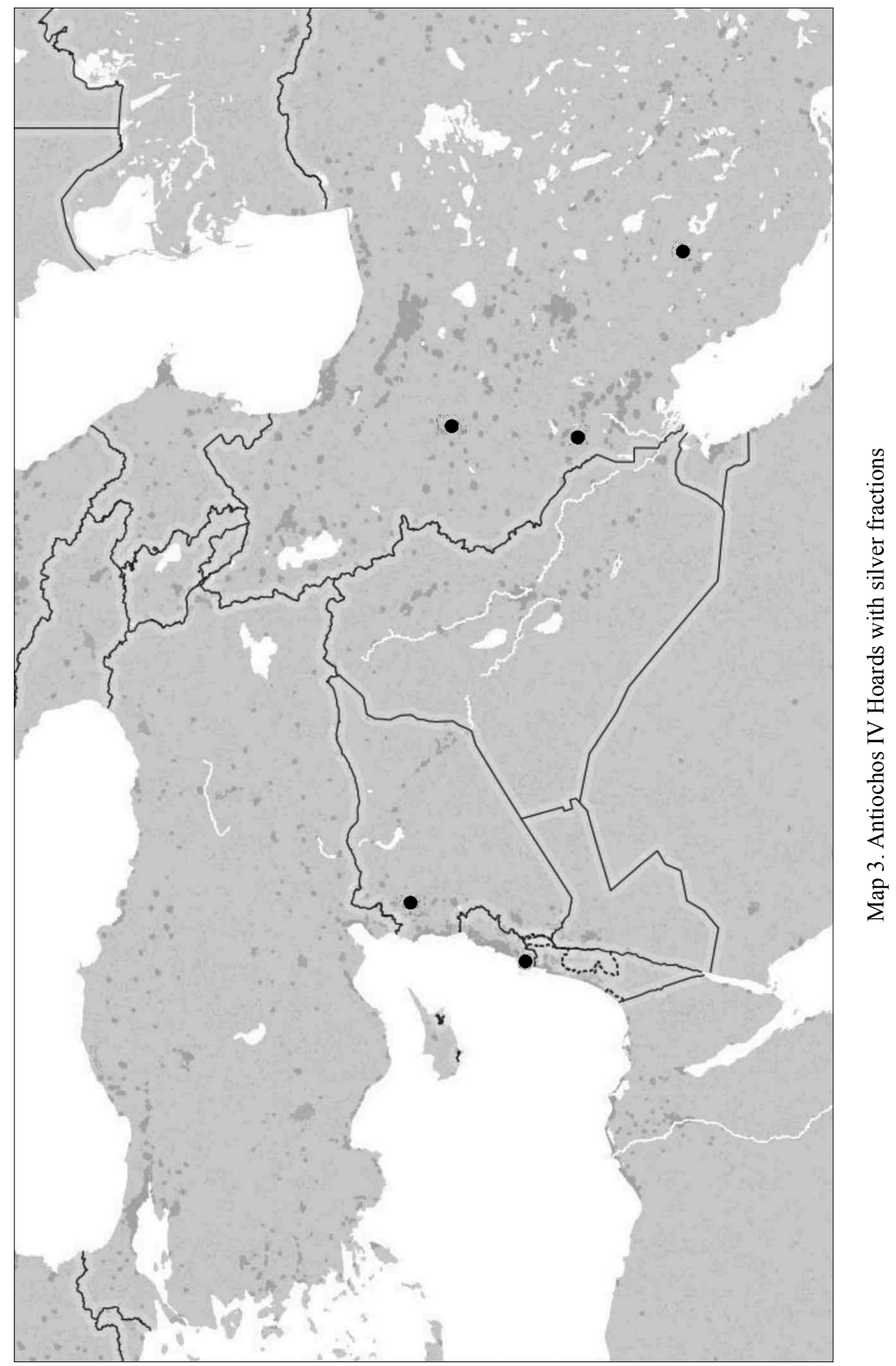




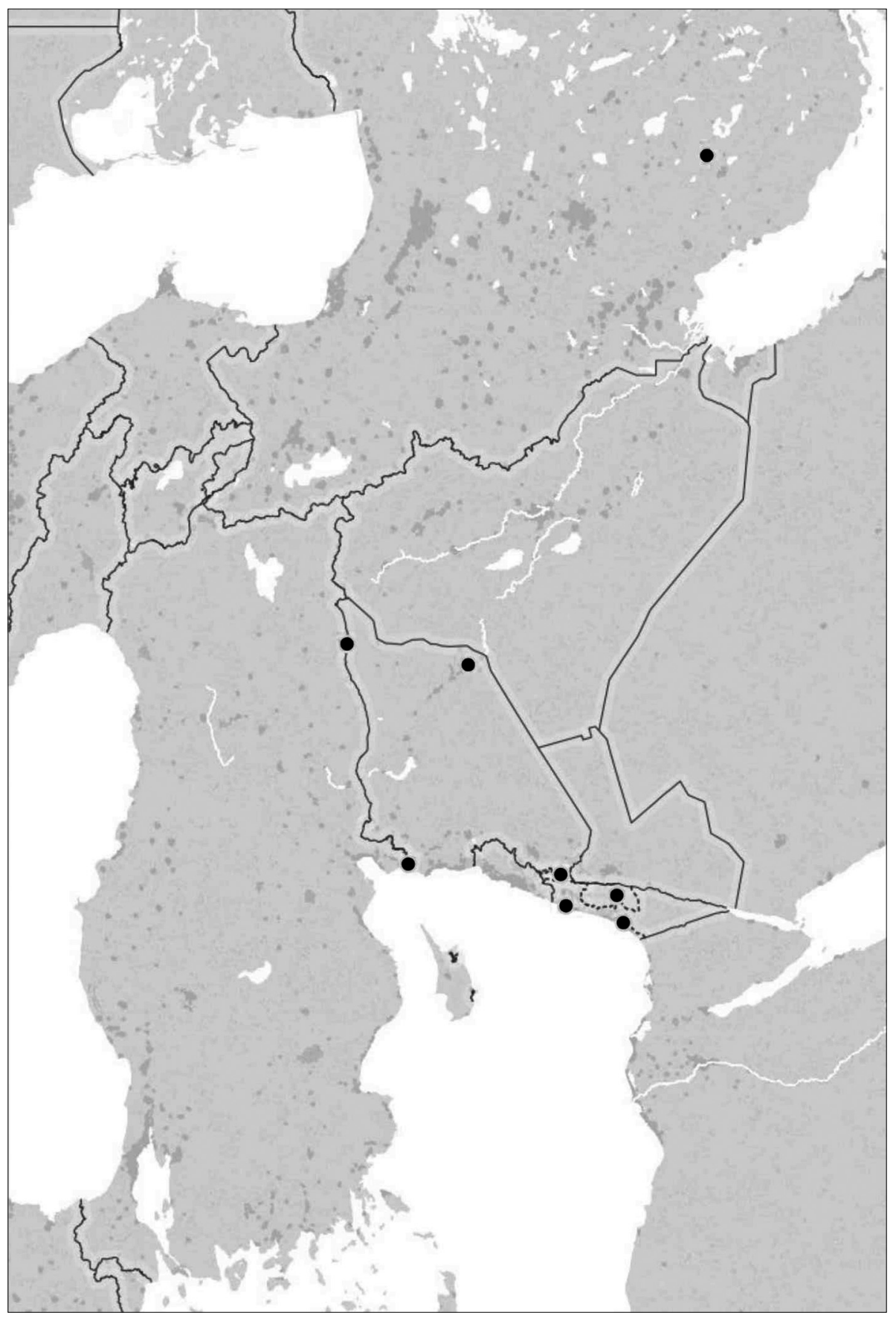

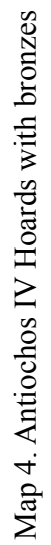


Of these hoards, only four are mixed (see Annex 1 for these hoards). As a next step, the data are divided by find spot (table 5).

Table 5. Coins of Antiochos IV (all metals and denominations) divided by region of burial

\begin{tabular}{|l|c|c|c|}
\hline \multicolumn{1}{|c|}{ Region } & \# of Tetradrachms & \# of Silver Fractions & \# of AEs \\
\hline Levant \& Syria & 150 & 7 & 273 \\
\hline Mesopotamia & 118 & 126 & 9 \\
\hline Unknown provenance & 61 & 0 & 5 \\
\hline Asia Minor & 41 & 0 & 0 \\
\hline Armenia & 35 & 0 & 0 \\
\hline Total & $\mathbf{4 0 5}$ & $\mathbf{1 3 3}$ & $\mathbf{2 8 7}$ \\
\hline
\end{tabular}

It comes as no surprise that most of Antiochos' tetradrachms circulated in the Levant and Syria since $37 \%$ of the larger denominations are found in hoards in this region. Mesopotamia is also an important area of circulation with $29 \%$ of tetradrachms buried in the central region of the realm. Contrary to what was observed for Antiochos III ${ }^{11}$ but well explained from the historical circumstances after the loss of Asia Minor in 189, Asia Minor represents only a minor area of circulation of Epiphanes' coins (10\%), a percentage comparable to the Armenian circulation patterns of the king's largest denominations. The smaller silver fractions, i.e. drachms, circulate mostly in Mesopotamia (95\%), especially because of the large productions of Ecbatana and the $\Xi \mathrm{AP}$ mint. ${ }^{12}$ On the other hand, Antiochos' IV bronzes found in hoards are mostly coming from the Levant and Syria $(95 \%)$ where the production of Ptolemais-Ake seems to play an important role. ${ }^{13}$

This image of spatial distribution of hoards containing coins issued by Antiochos IV should be completed by a chronological one. Table 6 divides Antiochos' IV coins by closure date (adopting the method of the decades for observing patterns). ${ }^{14}$

Most tetradrachms of Antiochos IV were buried during the two decades 170-151 $(119+115 ; 58 \%)$. This means that most of his tetradrachms were buried during the second phase of Antiochos' reign and Eupator's reign (119) or during that of Demetrios I (115). It comes as a surprise that no tetradrachms of the king are assigned a closure date during the first years of his reign, i.e. the decade 180-171. Tetradrachms of Epiphanes circulated for quite long periods since they are found in large quantities in hoards from 140-121. When it comes to drachms, the large majority (81\%) was buried in 150-141 hoards, while bronzes present two peaks in their closure phases: 42\% during Antiochos' reign and 55.5\% in 130-121. The spatio-chronological distribution of hoards with tetradrachms of Antiochos IV is summarized in table 7, where data from tables 5 and 6 are gathered together.

11 Iossif 2017, 47.

12 Houghton - Lorber - Hoover 2008, 115-119, nos 1539-1542 (tetradrachms) and 1543-1550 (drachms) [Ecbatana]; 121-123, nos 1558 (tetradrachm) and 1559 (drachms) [ $\Xi A P$ mint]. It is interesting to note that the authors of Seleucid Coins identified one variety for the tetradrachm and 14 for the drachms, a clear indication also of the size of these issues.

13 Houghton - Lorber - Hoover 2008, 87-92, nos 1477-1479.

14 Some coins bear no precise reference on the closure date which explains the different totals in this table. 
Table 6. Coins of Antiochos IV (all metals and denominations) divided by decade of closure (classified based on the largest amount of tetradrachms)*

\begin{tabular}{|c|c|c|c|}
\hline Decades & \# of Tetradrachms & \# of Silver Fractions & \# of AEs \\
\hline $170-161$ & 119 & 6 & 116 \\
\hline $160-151$ & 115 & 14 & 0 \\
\hline $140-131$ & 110 & 3 & 0 \\
\hline $150-141$ & 41 & 108 & 3 \\
\hline $130-121$ & 17 & 0 & 155 \\
\hline $80-71$ & 0 & 0 & 3 \\
\hline $90-81$ & 0 & 2 & 0 \\
\hline $100-91$ & 0 & 0 & 2 \\
\hline Total & $\mathbf{4 0 2}$ & $\mathbf{1 3 3}$ & $\mathbf{2 7 9}$ \\
\hline
\end{tabular}

* Differences in sums for this table are due to uncertainties with a few coins.

Table 7. Spatio-chronological distribution of tetradrachms of Antiochos IV

\begin{tabular}{|c|c|c|c|c|c|c|}
\hline $\begin{array}{c}\text { Decade } \\
\text { Region }\end{array}$ & $\begin{array}{c}\text { Levant } \\
\text { \& Syria }\end{array}$ & Mesopotamia & $\begin{array}{c}\text { Unknown } \\
\text { Provenance }\end{array}$ & Asia Minor & Armenia & Total \\
\hline $170-161$ & $\mathbf{1 1 1}$ & & 8 & & & $\mathbf{1 1 9}$ \\
\hline $160-151$ & 30 & 4 & $\mathbf{5 2}$ & 11 & $\mathbf{1 8}$ & $\mathbf{1 1 5}$ \\
\hline $140-131$ & 0 & $\mathbf{1 0 9}$ & & & 1 & $\mathbf{1 1 0}$ \\
\hline $150-141$ & 9 & 5 & & $\mathbf{2 7}$ & & $\mathbf{4 1}$ \\
\hline $130-121$ & 0 & & 1 & & 16 & $\mathbf{1 7}$ \\
\hline $80-71$ & & & 0 & & & $\mathbf{0}$ \\
\hline $90-81$ & & 0 & & & & $\mathbf{0}$ \\
\hline $100-91$ & 0 & & & & & $\mathbf{0}$ \\
\hline Total & $\mathbf{1 5 0}$ & $\mathbf{1 1 8}$ & $\mathbf{6 1}$ & $\mathbf{3 8}$ & $\mathbf{3 5}$ & $\mathbf{4 0 2}$ \\
\hline
\end{tabular}

The analysis of table 7 clearly shows that $74 \%$ of coins circulating in the Levant and Syria are buried during the last years of the king's reign and certainly following the Egyptian expeditions and the Sixth Syrian war. ${ }^{15}$ At the same time, the circulation of tetradrachms of the king in Mesopotamia seems to be longer, since $92.4 \%$ was buried in $140-131$ probably to be connected with the failed Parthian expedition of Demetrios II between spring/summer 139 and his defeat in the summer of $138 .{ }^{16}$ It comes as no surprise that the two central regions of the kingdom were the main areas of circulation of the king's tetradrachms; in both cases, the closure dates can be connected with military operations in these areas.

Table 8 offers a spatio-chronological analysis of drachms.

${ }^{15}$ Diod. 30.14; 30.18.2; Jos. $A J$ 12.242-243; Plb. 29.27.1-13. For the events of this period, see Mittag 2006, 171-175.

${ }^{16}$ I.Macc.14.1; Jos. AJ 13.184-186; Diod. 33.28; App. Syr. 67; Just. 36.1.5. 
Table 8. Spatio-chronological distribution of drachms of Antiochos IV

\begin{tabular}{|c|c|c|c|}
\hline Decade Regions & Levant \& Syria & Mesopotamia & Total \\
\hline $\mathbf{1 5 0}-\mathbf{1 4 1}$ & 0 & $\mathbf{1 0 8}$ & $\mathbf{1 0 8}$ \\
\hline $\mathbf{1 6 0}-\mathbf{1 5 1}$ & 0 & 14 & $\mathbf{1 4}$ \\
\hline $\mathbf{9 0 - 8 1}$ & & 2 & $\mathbf{2}$ \\
\hline $\mathbf{1 4 0 - 1 3 1}$ & 1 & 2 & $\mathbf{3}$ \\
\hline $\mathbf{1 7 0}-\mathbf{1 6 1}$ & 6 & & $\mathbf{6}$ \\
\hline $130-121$ & 0 & & $\mathbf{0}$ \\
\hline $100-91$ & 0 & & $\mathbf{0}$ \\
\hline Total & 7 & $\mathbf{1 2 6}$ & $\mathbf{1 3 3}$ \\
\hline
\end{tabular}

Drachms (and other silver fractions) circulated mostly in Mesopotamia and only small quantities reached the Levant and Syria. $86 \%$ of coins circulating in Mesopotamia were buried during the years 150-141. This image is different from what we observe for bronzes which were buried mostly in hoards from the Levant and Syria, as can be seen in table 9.

Table 9. Spatio-chronological distribution of bronzes of Antiochos IV

\begin{tabular}{|c|c|c|c|c|}
\hline Decade Regions & Levant \& Syria & Mesopotamia & Unknown Provenance & Total \\
\hline $100-91$ & 2 & & & $\mathbf{2}$ \\
\hline $130-121$ & $\mathbf{1 5 5}$ & & 0 & $\mathbf{1 5 5}$ \\
\hline $140-131$ & 0 & 0 & & $\mathbf{0}$ \\
\hline $150-141$ & 0 & 3 & 0 & $\mathbf{3}$ \\
\hline $160-151$ & 0 & 0 & 0 & $\mathbf{0}$ \\
\hline $170-161$ & 116 & & 3 & $\mathbf{1 1 6}$ \\
\hline $80-71$ & & & & $\mathbf{3}$ \\
\hline $90-81$ & & 0 & $\mathbf{3}$ & $\mathbf{0}$ \\
\hline Total & $\mathbf{2 7 3}$ & $\mathbf{3}$ & & $\mathbf{2 7 9}$ \\
\hline
\end{tabular}

The next step in the analysis of the hoard data for Antiochos IV is the provenance of the produced issues, i.e. the possibility to determine the relative percentages of the most represented mints (table 10).

This table shows a predominance of Antioch as the major mint for tetradrachms under Antiochos IV. ${ }^{17}$ Antioch produces $64.4 \%$ of all tetradrachms under Antiochos IV; at the same time, a second occidental mint, relatively new in the Seleucid production, i.e. Ptolemais-Ake, occupies the second position with $22 \%$ of the total production. We recently argued that Antioch became the most productive Seleucid mint under the reign of Seleu-

17 See Iossif 2014, 36-37 and Iossif 2017, 49-50 for a discussion on the moment when Antioch becomes the major mint of the kingdom leaving Seleucia on the Tigris in the second place. 
Table 10. Number of coins issued under Antiochos IV (all metals and denominations) divided by mints

\begin{tabular}{|c|c|c|c|}
\hline Mint & \# of Tetradrachms & \# of Silver Fractions & \# of AEs \\
\hline Antioch & $\mathbf{2 6 1}$ & 7 & 3 \\
\hline Ptolemais-Ake & 89 & 0 & $\mathbf{2 5 4}$ \\
\hline Seleucia on the Tigris & 16 & 0 & 8 \\
\hline Susa & 9 & 0 & 0 \\
\hline Tarsos & 7 & 0 & 0 \\
\hline Unc. Mints & 6 & 15 & 2 \\
\hline EAP mint & 4 & $\mathbf{7 2}$ & 0 \\
\hline Ecbatana & 4 & 39 & 0 \\
\hline Mint 81 & 3 & 0 & 0 \\
\hline Mint 80 & 2 & 0 & 0 \\
\hline Soloi & 2 & 0 & 0 \\
\hline Seleucia Pieria & 2 & 0 & 0 \\
\hline Tyre & 0 & 0 & 2 \\
\hline Samaria & 0 & 0 & 18 \\
\hline Total & $\mathbf{4 0 5}$ & $\mathbf{1 3 3}$ & $\mathbf{2 8 7}$ \\
\hline
\end{tabular}

cos II and especially after the reign of Antiochos III, the western "capital" became the major coin provider for the kingdom. ${ }^{18}$ Seleucia on the Tigris followed the exact opposite movement since it was the most important mint until the reign of Antiochos II. In a 2017 article, we demonstrated that the ratio between Antioch and Seleucia on the Tigris under Antiochos III was established to a little more than 2.1:1 and following the extrapolation method, we estimated the number of dies used by Antiochos III in Seleucia on the Tigris to c. $28 .{ }^{19}$ The same analysis based on the extrapolation method can be used for estimating the original number of dies for both Ptolemais-Ake and Seleucia on the Tigris. Based, once more to Georges Le Rider's seminal die study for Antioch, we know that the number of dies produced under the reign of Epiphanes was for $n=565$ and $d=58$, then $D=60$ (with a 95\% confidence interval between 58 and 62; using Esty's formula). ${ }^{20}$ Table 10 allows for estimating the ratio between Antioch and Ptolemais-Ake to 3:1 and between Antioch and Seleucia on the Tigris to 16:1. Therefore, it is possible to estimate the number of dies used for producing the coins for these two mints to 20 for Ptolemais-Ake and 4 (3.8) for Seleucia on the Tigris. There is no doubt that Seleucia became a second level mint under Antiochos IV, as was already the case under Seleucos IV. ${ }^{21}$ Interestingly enough, and confirming the validity of the "extrapolation" method I developed, the die

\footnotetext{
18 Iossif 2014, 36-37.

19 Iossif 2015 and Iossif 2017, 50.

${ }^{20}$ Le Rider 1999, 190-233 (catalogue p. 190-222); Esty 2006.

21 Iossif 2017, 61, fig. 2.
} 
study of Ptolemais-Ake by Otto Mørkholm gave the following number of dies: for $\mathrm{n}=66$ and $d=14$, then $\mathrm{D}=16$ (with a $95 \%$ confidence interval between 14 and 18; using Esty's formula); hence, establishing a c. 3:1 ratio for the dies as well (varying from 4.2 to 3.3 for the minimal and maximal values of the estimated number of dies). ${ }^{22}$

The analysis of the spatio-chronological distribution of Antiochene coins is also revealing of circulation patterns (and of historical circumstances). Table 11 summarizes the data.

Table 11. Distribution of tetradrachms produced in Antioch under Antiochos IV

\begin{tabular}{|c|c|c|c|c|c|c|}
\hline $\begin{array}{c}\text { Decades/Burial } \\
\text { region }\end{array}$ & Armenia & Asia Minor & $\begin{array}{c}\text { Levant } \\
\text { \& Syria }\end{array}$ & Mesopotamia & $\begin{array}{c}\text { Unknown } \\
\text { Provenance }\end{array}$ & Total \\
\hline $170-161$ & & & $\mathbf{6 6}$ & & 6 & $\mathbf{7 2}$ \\
\hline $160-151$ & $\mathbf{1 4}$ & 9 & 15 & 2 & $\mathbf{4 2}$ & $\mathbf{8 2}$ \\
\hline $150-141$ & & $\mathbf{2 5}$ & 8 & 4 & & $\mathbf{3 7}$ \\
\hline $140-131$ & 1 & & 0 & $\mathbf{5 6}$ & & $\mathbf{5 7}$ \\
\hline $130-121$ & 12 & & & & 1 & $\mathbf{1 3}$ \\
\hline Total & $\mathbf{2 7}$ & $\mathbf{3 4}$ & $\mathbf{8 9}$ & $\mathbf{6 2}$ & $\mathbf{4 9}$ & $\mathbf{2 6 1}$ \\
\hline
\end{tabular}

Tetradrachms from Antioch were mostly buried in the Levant and Syria the decade 170-161 (74.2\%), most likely in connection with the Sixth Syrian War in which Antioch seemed to be the main coin supplier for the campaigning army (see also below for a comparable analysis from excavations data). Smaller quantities of tetradrachms of Antiochos IV circulated in the area for the next two decades. In Mesopotamia, the image is different since very few Antiochene tetradrachms reached the region (or were hoarded) until 150-141 and then, in 140-131, large quantities of coins from the occidental "capital" arrived en masse (c. $90 \%$ were hoarded at that period). A legitimate hypothesis would be to connect this arrival with the army of Demetrios II campaigning against the Parthians in that area; part of the army could have been paid with Antiochos IV tetradrachms. A considerable percentage of Epiphanes' tetradrachms is also found in hoards coming from Asia Minor and buried between 150-141 attesting, once more, than the Taurus mountain frontier allowed the circulation of Attic-weight issues in both directions; this westward presence of tetradrachms of Antiochos IV in Asia Minor could be connected with the presence of his "pretended" son, Alexander I Balas and his operations in the area. The presence of relatively numerous Antiochene tetradrachms in Armenian hoards closing between 160-151 is interesting and could be connected to the presence of the king in the region as attested by a Babylonian tablet recently re-edited and discussed by Philippe Clancier. ${ }^{23}$

22 Mørkholm 1963, 45-50 (for the catalogue).

${ }^{23}$ I would like to thank Cathy Lorber and Omar Coloru for discussions on this precise question. The logical explanation would be to connect the Armenian trend of hoards in 160-151 with military operations. In fact, if we follow the events as described in the very fragmentary astronomical diary $A D 2,-164$, the king operated in Hanigalbat (Armenia) slightly after 165. For a recent analysis of this astronomical diary, the way the expedition happened, and the definition of Hanigalbat as Armenia, see Clancier 2014, 359-365. This analysis of the diary argues in favor of Omar Coloru's hypothesis of a passage of Epiphanes from Caucasus; see Coloru 2014, 402-409. 
The situation of the Antiochene distribution becomes even more interesting when compared with that of Seleucia on the Tigris.

Table 12. Distribution of tetradrachms produced in Seleucia on the Tigris under Antiochos IV

\begin{tabular}{|c|c|c|c|}
\hline $\begin{array}{c}\text { Decades/Burial } \\
\text { Region }\end{array}$ & Armenia & Mesopotamia & Total \\
\hline $150-141$ & & $\mathbf{1 5}$ & $\mathbf{0}$ \\
\hline $140-131$ & 1 & & $\mathbf{1}$ \\
\hline $130-121$ & $\mathbf{1}$ & $\mathbf{1 5}$ & $\mathbf{1 6}$ \\
\hline Total & & & \\
\hline
\end{tabular}

Coins from the Eastern "capital" of the kingdom produced under Antiochos IV are exclusively limited to areas in the East, in general not far from their production mint; coins of Seleucia are buried in hoards from Armenia (but the number is too small for any reliable conclusion) and especially in Mesopotamia. This image of a "local" circulation of the Seleucian production corroborates what we observed already under Antiochos III. ${ }^{24}$ Seleucia is downgraded as a regional mint and its production offers no serious impact on the kingdom-wide numismatic production.

More important is to compare Antioch with the production of Ptolemais-Ake. This city fell recently into the hands of the Seleucids and started operating as a mint under the reign of Antiochos III. ${ }^{25}$ Table 13 offers the spatio-chronological analysis for Ptolemais-Ake.

Table 13. Distribution of tetradrachms produced in Ptolemais-Ake under Antiochos IV

\begin{tabular}{|c|c|c|c|c|c|c|}
\hline $\begin{array}{c}\text { Decades/Burial } \\
\text { region }\end{array}$ & Armenia & Asia Minor & $\begin{array}{c}\text { Levant } \\
\text { \& Syria }\end{array}$ & Mesopotamia & $\begin{array}{c}\text { Unknown } \\
\text { Provenance }\end{array}$ & Total \\
\hline $170-161$ & & & $\mathbf{3 8}$ & & 2 & $\mathbf{4 0}$ \\
\hline $160-151$ & $\mathbf{4}$ & 2 & 15 & 2 & $\mathbf{9}$ & $\mathbf{3 2}$ \\
\hline $150-141$ & & 2 & 1 & 1 & & $\mathbf{4}$ \\
\hline $140-131$ & & & & $\mathbf{1 0}$ & & $\mathbf{1 0}$ \\
\hline $130-121$ & 3 & & 0 & & & $\mathbf{3}$ \\
\hline Total & $\mathbf{7}$ & $\mathbf{4}$ & $\mathbf{5 4}$ & $\mathbf{1 3}$ & $\mathbf{1 1}$ & $\mathbf{8 9}$ \\
\hline
\end{tabular}

Tetradrachms of Ptolemais-Ake in the name of Antiochos IV circulate mostly in Levant and Syria (c. 61\%), while most of them are buried during Epiphanes' reign (45\%) and the decade following his death $(36 \%)$. One important feature of the circulation of tetradrachms

${ }^{24}$ See Iossif 2017, 51-52.

${ }_{25}$ Ptolemais-Ake was an annex mint of Antiochos III for small-denomination bronzes and started minting silver tetradrachms under Seleucos IV; Mørkholm 1965/1966, 8-9; Voulgaridis 2000, 8-9; Houghton - Lorber - Hoover 2008, 22-23, nos 1331 for the tetradrachm of the mint under Seleucos IV. 
from Ptolemais-Ake is that a relatively high percentage arrives in Mesopotamia (11\%) with the majority of these coins being buried in 140-131 (77\%). This pattern is exactly the same as the one we observed for Antioch and the "massive" arrival of occidental tetradrachms in Mesopotamia around 140-131 leaves no doubt that these coins followed a massive eastward movement within the realm, very likely that of the campaigning army of Demetrios II. This high correlation between the circulation (and closure) patterns of Antioch and Ptolemais-Ake is illustrated in table 14 based on a correlation coefficient $r$ and $r^{2}$ (with a very high average coefficient of determination [average of $r^{2}$ ] of $81.4 \%$ ). ${ }^{26}$

Table 14. Correlation coefficient $\mathrm{r}$ and $\mathrm{r}^{2}$ for closure patterns between Antioch and Ptolemais-Ake

\begin{tabular}{|c|c|c|c|c|c|c|}
\hline ANTIOCH & $170-161$ & $0 \%$ & $0 \%$ & $92 \%$ & $0 \%$ & $8 \%$ \\
\hline & $160-151$ & $17 \%$ & $11 \%$ & $18 \%$ & $2 \%$ & $51 \%$ \\
\hline & $150-141$ & $0 \%$ & $68 \%$ & $22 \%$ & $11 \%$ & $0 \%$ \\
\hline & 140-131 & $2 \%$ & $0 \%$ & $0 \%$ & $98 \%$ & $0 \%$ \\
\hline & 130-121 & $92 \%$ & $0 \%$ & $0 \%$ & $0 \%$ & $8 \%$ \\
\hline & Total & $10 \%$ & $13 \%$ & $34 \%$ & $24 \%$ & $19 \%$ \\
\hline \multirow[t]{6}{*}{ PTOLEMAIS-AKE } & $170-161$ & $0 \%$ & $0 \%$ & $95 \%$ & $0 \%$ & $5 \%$ \\
\hline & 160-151 & $13 \%$ & $6 \%$ & $47 \%$ & $6 \%$ & $28 \%$ \\
\hline & $150-141$ & $0 \%$ & $50 \%$ & $25 \%$ & $25 \%$ & $0 \%$ \\
\hline & 140-131 & $0 \%$ & $0 \%$ & $0 \%$ & $100 \%$ & $0 \%$ \\
\hline & 130-121 & $100 \%$ & $0 \%$ & $0 \%$ & $0 \%$ & $0 \%$ \\
\hline & Total & $8 \%$ & $4 \%$ & $61 \%$ & $15 \%$ & $12 \%$ \\
\hline \multirow{7}{*}{$\begin{array}{c}\text { CORRELATION } \\
\text { COEFFICIENT } \\
r \text { and } r^{2} \\
\end{array}$} & & $\mathbf{r}$ & $\mathbf{r}^{2}$ & & & \\
\hline & $170-161$ & 0.99926921 & $99.9 \%$ & & & \\
\hline & $160-151$ & 0.45894543 & $21.1 \%$ & & & \\
\hline & 150-141 & 0.93245229 & $86.9 \%$ & & & \\
\hline & 140-131 & 0.99984922 & $100.0 \%$ & & & \\
\hline & 130-121 & 0.99662199 & $99.3 \%$ & & & \\
\hline & Total & 0.90458579 & $81.8 \%$ & & & \\
\hline
\end{tabular}

The nature of SHD, as already demonstrated in a series of recent articles, offers more extensive possibilities for the analysis of the mints producing coins for Antiochos IV. ${ }^{27}$ In

${ }_{26}$ The raw data are coming from tables 11 and 13 above. For methodological reasons, a correlation cannot be applied to the ensemble of data. On the contrary, it is possible to determine correlations by periods as has been done in table 14. As in case of every sample though, it must be pointed out that the quality of these values strongly depends on the size of the sample. I would like to thank Jan Moens for long discussions on this question and for his help establishing the correlations.

${ }^{27}$ Iossif 2011a, 2014, 2015, 2016, 2017. 
SHD, every mint bears an identity ('ID mint') which describes the nature of the mint based on historical information. Thus, I identified: "Capital cities," "Major cities," "Cities," "Military mints," "Military mints/cities." 28 The image for Antiochos IV is as follows:

Table 15. Distribution of coins (all metals and denominations) of Antiochos IV by mint "identity"

\begin{tabular}{|c|c|c|c|}
\hline ID Mint & \# of Tetradrachms & \# of Silver Fractions & \# of AEs \\
\hline “Capital” & 279 & 7 & 13 \\
\hline Cities & 9 & 0 & 18 \\
\hline Major cities & 102 & 39 & 256 \\
\hline Military mint/City & 9 & 73 & 0 \\
\hline (blank) & 6 & 14 & 0 \\
\hline Total & $\mathbf{4 0 5}$ & $\mathbf{1 3 3}$ & $\mathbf{2 8 7}$ \\
\hline
\end{tabular}

Table 15 shows that the great majority of tetradrachms issued by Antiochos IV were produced in well-established cities, especially in the so-called "capitals." Only a small fraction of the total percentage is attributed to facilities which might bear the character of a "military mint" (c. 2.2\%) showing that Epiphanes' monetary policy, pretty much like that of his father, was based on the already existing network of monetary facilities throughout his realm. ${ }^{29}$ Of course, the production of Antioch greatly influences this picture, since $64 \%$ of Antiochos' issues are attributed to the western "capital." Drachms were produced in very high percentages by "major cities" and "military mints/cities," a pattern already observed under the reign of Antiochos III where $64 \%$ of drachms were also produced by mints bearing the identity "military mint/city." ${ }^{30}$ Bronzes in the name of Antiochos IV are primarily produced in "major cities" (89.2\%), while capitals only produce a mere $4.5 \%$ of what we gathered in SHD; once more, the pattern is contrary to the practice under Antiochos III, where "capitals" produced c. $70 \%$ of all bronzes in SHD.

One last point of interest for the analysis of mints in SHD is their origin.

Table 16. Distribution of coins (all metals and denominations) of Antiochos IV by mint location

\begin{tabular}{|c|c|c|c|}
\hline Region of mint & \# of Tetradrachms & \# of Silver Fractions & \# of AEs \\
\hline Levant \& Syria & $\mathbf{3 5 2}$ & 7 & $\mathbf{2 7 7}$ \\
\hline Mesopotamia & 38 & $\mathbf{1 1 2}$ & 8 \\
\hline Asia Minor & 9 & 0 & 0 \\
\hline (blank) & 6 & 14 & 2 \\
\hline Total & $\mathbf{4 0 5}$ & $\mathbf{1 3 3}$ & $\mathbf{2 8 7}$ \\
\hline
\end{tabular}

${ }^{28}$ Cf. Capdetrey 2007 for a categorization of Seleucid cities.

${ }^{29}$ Iossif 2017, 55 and passim.

${ }^{30}$ Iossif 2017, 55, table 14. 


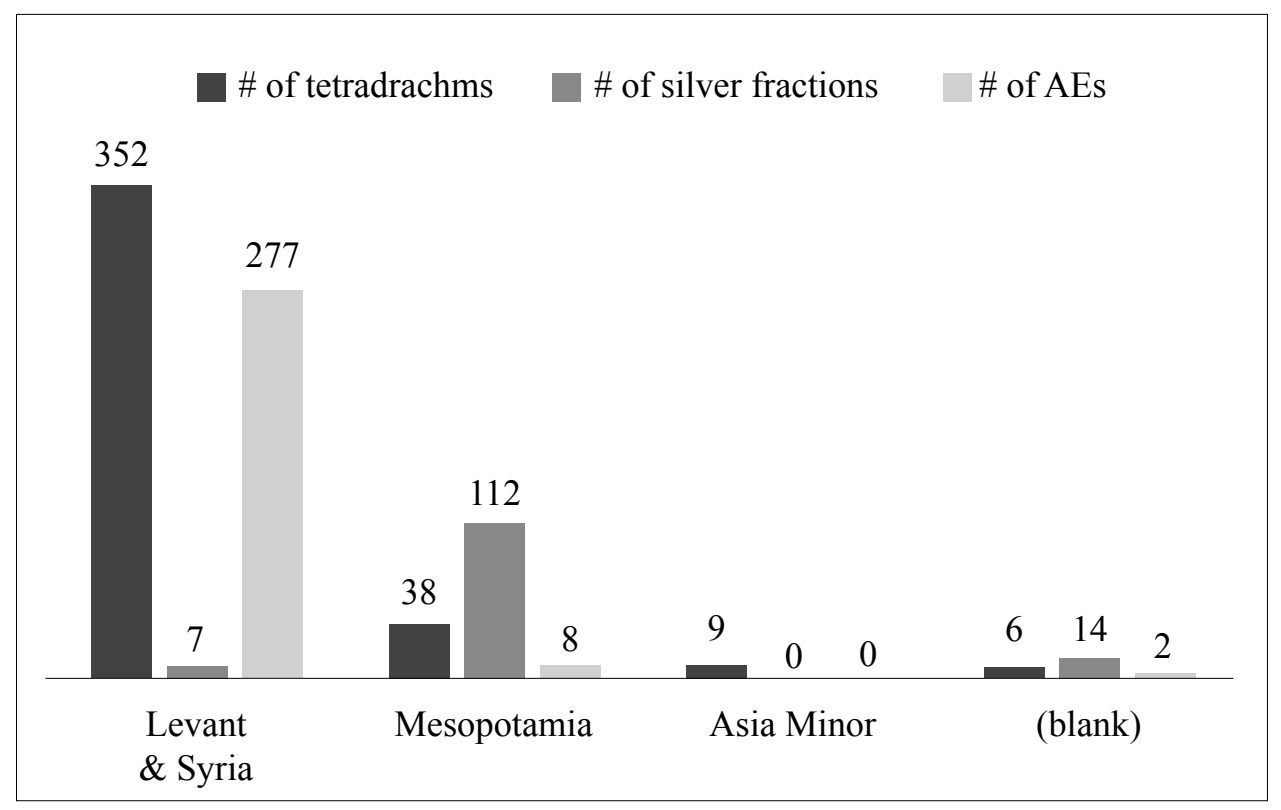

Figure 1. Distribution of coins (all metals and denominations) of Antiochos IV by mint location

Table 16 and figure 1 show that the bulk of Epiphanes' tetradrachms was produced in Syrian mints (c. 87\%). Only a small fraction of his tetradrachms was produced in Mesopotamian mints $(9.4 \%)$. This shows a quite limited distribution of tetradrachms since, as we have seen in tables 5 and 7, most of Antiochus' tetradrachms were buried in hoards found in the Levant and Syria (37\%). On the other hand, Mesopotamia which produced less than $10 \%$ of Epiphanes' tetradrachms in hoards was the end point of more than $29 \%$ of his coins. This is a clear indication of an important and systematic eastward circulation pattern of coins produced in the occidental part and ending their lives in Mesopotamia. The clear predominance of Antioch (and Ptolemais-Ake) over Seleucia on the Tigris (16:1 ratio) is the reason for this movement to the East, since the area seems to produce only limited amounts of coins and the royal army was rarely present in the region.

One of the main advantages of big databases is that they allow deeper analyses of the raw data asking questions impossible even to imagine before the creation of such datasets. In the reign under consideration, it is possible to determine the relative importance of numismatic types, divide them by obverse and/or reverse types, define geographical patterns for a given type or determine the preferred deity (-ies) of the king. Some initial iconographic data of the coinage of Antiochos IV will allow us to set the first clues on the role of numismatic imagery as tool for diplomatic relationships or for legitimization of a reign. First Antiochos' coins are divided by obverse types:

Contrary to what we observed for the coins of Antiochos III, ${ }^{31}$ where virtually all tetradrachms bear the head of the king as their obverse type, the tetradrachms of Epiphanes present a greater variety of types and introduce what I defined elsewhere as the "divine

\footnotetext{
${ }^{31}$ Iossif 2017, 56-57.
} 
Table 17. Distribution of coins (all metals and denominations) of Antiochos IV by obverse type

\begin{tabular}{|c|c|c|c|}
\hline Obverse type & \# of Tetradrachms & \# of Silver Fractions & \# of AEs \\
\hline Antiochos IV with stars diadem ends & 276 & 0 & 0 \\
\hline Head of Antiochos IV & 72 & 132 & 2 \\
\hline Antiochos IV star forehead & 27 & 1 & 0 \\
\hline Zeus & 16 & 0 & 0 \\
\hline Antiochos IV with horn & 12 & 0 & 0 \\
\hline Apollo & 2 & 0 & 24 \\
\hline Antiochos IV with radiated crown & 0 & 0 & 156 \\
\hline Laodice IV veiled with stephane & 0 & 0 & 105 \\
\hline Total & $\mathbf{4 0 5}$ & $\mathbf{1 3 3}$ & $\mathbf{2 8 7}$ \\
\hline
\end{tabular}

types," i.e. coins where the king is presented wearing divine attributes. ${ }^{32} 68 \%$ of tetradrachms represent the king with stars at the diadem ends, while the percentage of "divine types" goes up to c. $78 \%$ if we calculate all different "divine types" on the obverse of his coins. Epiphanes generalized the use of divine attributes, especially considering the precious metal issues. ${ }^{33}$ Smaller silver denominations are dominated by "traditional types," i.e., the portrait of the king without any attribute, while bronzes make extensive use of the head of the king with radiate crown or, for the first time, the veiled head of a queen wearing a stephane. ${ }^{34}$

Antioch is responsible for a large part of these "divine types" since 219 tetradrachms with the head of Epiphanes with star adorning his diadem ends are produced in the occidental "capital" ( $54 \%$ of the total and $69.5 \%$ of the "divine types"). The same mint issued a small number of silver fractions (only seven) and even less bronzes (three). Table 18 shows the geographic distribution of "divine" tetradrachms from Antioch:

Table 18. Distribution of "divine" tetradrachms of Antiochos IV from Antioch by obverse type

\begin{tabular}{|c|c|c|c|c|c|c|}
\hline $\begin{array}{c}\text { Obverse types from } \\
\text { Antioch/Distribution }\end{array}$ & $\begin{array}{c}\text { Levant } \\
\text { \& Syria }\end{array}$ & Mesopotamia & $\begin{array}{c}\text { Unknown } \\
\text { Provenance }\end{array}$ & $\begin{array}{c}\text { Asia } \\
\text { Minor }\end{array}$ & Armenia & Total \\
\hline Head of Antiochos IV & 13 & 1 & 6 & & 5 & $\mathbf{2 5}$ \\
\hline $\begin{array}{c}\text { Antiochos IV with stars } \\
\text { diadem ends }\end{array}$ & $\mathbf{6 6}$ & $\mathbf{5 8}$ & $\mathbf{4 0}$ & $\mathbf{3 4}$ & $\mathbf{2 1}$ & $\mathbf{2 1 9}$ \\
\hline Apollo & 2 & & & & & $\mathbf{2}$ \\
\hline Zeus & 8 & 3 & 3 & & 1 & $\mathbf{1 5}$ \\
\hline Total & $\mathbf{8 9}$ & $\mathbf{6 2}$ & $\mathbf{4 9}$ & $\mathbf{3 4}$ & $\mathbf{2 7}$ & $\mathbf{2 6 1}$ \\
\hline
\end{tabular}

${ }^{32}$ Iossif 2012, passim; Iossif, 2018.

${ }^{33}$ See Iossif 2011a and Iossif 2012 for an analysis of previous practices, especially of horned portraits on bronzes.

${ }^{34}$ For the identification of this queen with Laocide IV, see Hoover 2002. 
Antiochene "divine" tetradrachms circulated quite extensively and in high numbers not only in the Levant and Syria but also in Mesopotamia (almost in equal quantities), and in Asia Minor and Armenia, areas notably outside the borders of the kingdom. Tables 19-22 divide the Antiochene "divine" tetradrachms by burial region and decade.

Table 19. Distribution of Antiochene "divine" tetradrachms of Antiochos IV by obverse type by closure decade in Levant and Syria

\begin{tabular}{|c|c|c|c|c|c|}
\hline Obverse types from Antioch/Decade & $\mathbf{1 7 0 - 1 6 1}$ & $\mathbf{1 6 0 - 1 5 1}$ & $\mathbf{1 5 0 - 1 4 1}$ & $\mathbf{1 4 0 - 1 3 1}$ & Total \\
\hline Head of Antiochos IV & 6 & 0 & 7 & 0 & $\mathbf{1 3}$ \\
\hline Antiochos IV with stars diadem ends & $\mathbf{5 0}$ & 15 & 1 & 0 & $\mathbf{6 6}$ \\
\hline Apollo & 2 & 0 & 0 & 0 & $\mathbf{2}$ \\
\hline Zeus & 8 & 0 & 0 & 0 & $\mathbf{8}$ \\
\hline Total & $\mathbf{6 6}$ & $\mathbf{1 5}$ & $\mathbf{8}$ & $\mathbf{0}$ & $\mathbf{8 9}$ \\
\hline
\end{tabular}

Table 20. Distribution of Antiochene "divine" tetradrachms of Antiochos IV by obverse type by closure decade in Mesopotamia

\begin{tabular}{|c|c|c|c|c|c|}
\hline Obverse types from Antioch/Decade & $\mathbf{1 7 0 - 1 6 1}$ & $\mathbf{1 6 0 - 1 5 1}$ & $\mathbf{1 5 0 - 1 4 1}$ & $\mathbf{1 4 0 - 1 3 1}$ & Total \\
\hline Head of Antiochos IV & 0 & 1 & 0 & 0 & $\mathbf{1}$ \\
\hline Antiochos IV with stars diadem ends & & 0 & 4 & $\mathbf{5 4}$ & $\mathbf{5 8}$ \\
\hline Laodice IV veiled with stephane & 0 & 0 & 0 & 0 & $\mathbf{0}$ \\
\hline Zeus & 0 & 1 & 0 & 2 & $\mathbf{3}$ \\
\hline Total & $\mathbf{0}$ & $\mathbf{2}$ & $\mathbf{4}$ & $\mathbf{5 6}$ & $\mathbf{6 2}$ \\
\hline
\end{tabular}

Table 21. Distribution of Antiochene "divine" tetradrachms of Antiochos IV by obverse type by closure decade in Asia Minor

\begin{tabular}{|c|c|c|c|c|c|}
\hline Obverse types from Antioch/Decade & $\mathbf{1 7 0 - 1 6 1}$ & $\mathbf{1 6 0 - 1 5 1}$ & $\mathbf{1 5 0}-\mathbf{1 4 1}$ & $\mathbf{1 4 0 - 1 3 1}$ & Total \\
\hline Antiochos IV with stars diadem ends & 0 & 9 & $\mathbf{2 5}$ & 0 & $\mathbf{3 4}$ \\
\hline Total & 0 & 9 & $\mathbf{2 5}$ & $\mathbf{0}$ & $\mathbf{3 4}$ \\
\hline
\end{tabular}

Table 22. Distribution of Antiochene "divine" tetradrachms of Antiochos IV by obverse type by closure decade in Armenia

\begin{tabular}{|c|c|c|c|c|c|c|}
\hline Obverse types from Antioch/Decade & $\mathbf{1 7 0 - 1 6 1}$ & $\mathbf{1 6 0 - 1 5 1}$ & $\mathbf{1 5 0 - 1 4 1}$ & $\mathbf{1 4 0 - 1 3 1}$ & $\mathbf{1 3 0 - 1 2 1}$ & Total \\
\hline Antiochos IV with stars diadem ends & 0 & $\mathbf{1 3}$ & 0 & 0 & 8 & $\mathbf{2 1}$ \\
\hline Head of Antiochos IV & 0 & 1 & 0 & 0 & 4 & $\mathbf{5}$ \\
\hline Zeus & 0 & 0 & 0 & 1 & 0 & $\mathbf{1}$ \\
\hline Total & $\mathbf{0}$ & $\mathbf{1 4}$ & $\mathbf{0}$ & $\mathbf{1}$ & $\mathbf{1 2}$ & $\mathbf{2 7}$ \\
\hline
\end{tabular}


In the Levant and Syria, 50 "divine" tetradrachms were buried already in 170-161 while in Mesopotamia, the same tetradrachms arrived later and were hoarded mainly in 140-131 (54 coins). In Asia Minor, the main bulk of Epiphanes" "divine" tetradrachms was buried in 150-141 (25) and in Armenia in almost equal quantities between 160-151 and 130-121. Once more, the tetradrachms of Antioch follow a massive movement from the West to Mesopotamia in 140-131 and it is more than possible that they followed the movement of the royal army of Demetrios II (see above). The presence of "divine" tetradrachms outside the Seleucid realm for long periods after his reign could argue in favor of the impact this imagery had on the neighbors of the kingdom, as well as on the large quantities these coins were produced by Antiochos IV in order to assess his power.

The reverse types present the following image.

Table 23. Distribution of coins (all metals and denominations) of Antiochos IV by reverse type

\begin{tabular}{|c|c|c|c|}
\hline Reverse types & \# of Tetradrachms & \# of Silver Fractions & \# of AEs \\
\hline Zeus Nicephoros & 331 & 0 & 0 \\
\hline Apollo seated omphalos & 71 & 133 & 21 \\
\hline Apollo standing & 2 & 0 & 1 \\
\hline Apollo seated omphalos star & 1 & 0 & 0 \\
\hline Female figure standing & 0 & 0 & 130 \\
\hline Eagle & 0 & 0 & 1 \\
\hline Elephant head & 0 & 0 & 105 \\
\hline Palm tree & 0 & 0 & 2 \\
\hline Tyche wearing polos & 0 & 0 & 2 \\
\hline Tyche holding cornucopia & 0 & 0 & 3 \\
\hline Artemis standing & 0 & 0 & 21 \\
\hline Goddess nicephoros enthroned & 0 & 0 & $\mathbf{2 8 7}$ \\
\hline Total & $\mathbf{4 0 5}$ & $\mathbf{1 3 3}$ & \\
\hline
\end{tabular}

As I already demonstrated in a 2011 article, the reign of Epiphanes represents a serious shift in the reverse types adopting Zeus Nicephoros as the main trademark of the dynasty replacing Apollo. ${ }^{35}$ This change affects mostly the larger denominations, i.e., tetradrachms, and is virtually absent from smaller silver fractions and bronze issues. Almost $82 \%$ of Antiochos' tetradrachms bear the new reverse dynastic type, while the rest continues the use of the Apollo seated on the omphalos type. This last type is mostly issued in the East of the realm (41 out of 71 coins), while Ptolemais-Ake is the most prolific occidental mint producing tetradrachms with Apollo.

The choice of the new type and its direct connection to the largest denominations generally used to pay the soldiers and larger economic exchanges can only be intentional focusing on targeted audiences of users. Antiochos IV placed his reign under the auspices

\footnotetext{
35 Iossif 2011a, 226-237; Iossif 2011b.
} 
of Zeus and the promotion of this new religious and diplomatic choice was made public through its association with the coins which travelled faster and longer. In that respect, it is interesting to note that the smaller silver fractions virtually ignored this new choice since all data in SHD are of the Apollo seated on the omphalos type and limited to eastern, Mesopotamian mints. ${ }^{36}$ The bronzes, on the other hand, while also ignoring the new dynastic type introduced by Antiochos IV, present a larger variety. Another explanation, not really contradictory to the previous one, could be a form of divine hierarchy: Zeus, the greatest of the Greek pantheon, dominated the most valuable of the king's coinage.

The new dynastic type of Zeus Nicephoros was produced in large quantities mostly in Antioch as can be seen below, while Ptolemais-Ake also considerably contributed to this production.

Table 24. Mints producing Zeus Nicephoros tetradrachms of Antiochos IV

\begin{tabular}{|c|c|}
\hline Mint & \# of Tetradrachms \\
\hline Antioch & 252 \\
\hline Ptolemais-Ake & 77 \\
\hline Unc. mint & 2 \\
\hline Total & $\mathbf{3 3 1}$ \\
\hline
\end{tabular}

Table 25 considers the spatio-chronological distribution of the 331 Zeus Nicephoros tetradrachms:

Table 25. Spatio-chronological distribution of Zeus Nicephoros tetradrachms of Antiochos IV

\begin{tabular}{|c|c|c|c|c|c|c|}
\hline Burial region/Date & $\mathbf{1 7 0 - 1 6 1}$ & $\mathbf{1 6 0 - 1 5 1}$ & $\mathbf{1 5 0 - 1 4 1}$ & $\mathbf{1 4 0 - 1 3 1}$ & $\mathbf{1 3 0 - 1 2 1}$ & Total \\
\hline Levant \& Syria & $\mathbf{9 3}$ & 30 & 9 & & & $\mathbf{1 3 2}$ \\
\hline Mesopotamia & & 3 & 5 & $\mathbf{6 4}$ & & $\mathbf{7 2}$ \\
\hline Unknown provenance & 8 & $\mathbf{5 1}$ & & & 1 & $\mathbf{6 0}$ \\
\hline Asia Minor & & 11 & $\mathbf{2 7}$ & & & $\mathbf{3 8}$ \\
\hline Armenia & & 17 & & 1 & $\mathbf{1 1}$ & $\mathbf{2 9}$ \\
\hline Total & $\mathbf{1 0 1}$ & $\mathbf{1 1 2}$ & $\mathbf{4 1}$ & $\mathbf{6 5}$ & $\mathbf{1 2}$ & $\mathbf{3 3 1}$ \\
\hline
\end{tabular}

Most of these coins were buried in the Levant and Syria (c. $40 \%$ ), while $70 \%$ of the tetradrachms in the area was already buried in 170-161. Again, as observed previously, these coins arrived massively in Mesopotamia in 140-131 and also reached Asia Minor in the $150-141$ period.

The introduction of this new type made Zeus the dominant divine figure of the dynasty, an important change, especially considering the domination of Apollo, so obvious in the coinages of Antiochos III or Seleucos IV. ${ }^{37}$

\footnotetext{
${ }^{36}$ See Iossif - Lorber (2007), 80, n. 73 for Apollo's presence in the East.

${ }^{37}$ Iossif 2017, 57-58.
} 
Table 26. Distribution of coins (all metals and denominations) of Antiochos IV by reverse type deity

\begin{tabular}{|c|c|c|c|}
\hline Reverse deity & \# of Tetradrachms & \# of Silver Fractions & \# of AEs \\
\hline Zeus & 331 & 0 & 0 \\
\hline Apollo & 74 & 133 & 22 \\
\hline Varia & 0 & 0 & 259 \\
\hline Artemis & 0 & 0 & 1 \\
\hline Tyche & 0 & 0 & 5 \\
\hline Total & $\mathbf{4 0 5}$ & $\mathbf{1 3 3}$ & $\mathbf{2 8 7}$ \\
\hline
\end{tabular}

There is no doubt that Antiochos IV Epiphanes wishes to promote a new patron, especially in the occidental part of his kingdom and in connection with his numerous military operations in the area. In that respect, the numismatic imagery especially affecting the larger issues of the Seleucid denominational system, served as a perfect tool for promoting the king's new policy towards his neighbors, especially the Ptolemies who promoted Zeus (through his eagle) as their patron. ${ }^{38}$ The Seleucids under Epiphanes are willing to counterbalance the Ptolemaic propaganda associating them with the Achaemenids and especially the figure of Xerxes ${ }^{39}$; Epiphanes' choice is to present the Seleucids as the guarantors of Hellenism in the vast territories of the East and this new diplomatic attitude is perfectly translated into his numismatic choices and policies. ${ }^{40}$

\section{Conclusions}

The detailed analysis of SHD data for Antiochos IV offers some interesting conclusions. Antioch is by far the most prolific mint for the new king producing large volumes of tetradrachms most of which are buried in the area of the Levant and Syria already under the final years of his reign (170-161). The same mint also introduced in quantities the new dynastic type of Zeus Nicephoros. Both the introduction of the new typology, as well as the closure within the reign of Antiochos are to be connected with the numerous

38 The exact reasons why Antiochos IV Epiphanes promoted Zeus as his patron deity are not clear in the actual state of documentation. One possible explanation is that Epiphanes chose Zeus because this god was more easily comparable to the Jewish YHWH and the numerous Semitic Baals (after all, Zeus mostly appeared in the occidental part of his kingdom). Another explanation might have been the association of Apollo (especially of Apollo Toxotes seated on the omphalos; see Iossif [2011b]) with Oriental deities; considering the fact that, following hostile Jewish sources, Antiochos was a champion of Hellenism, then a close association of Apollo with Oriental aspects might have been counterproductive for the king's new policy. Hence, the choice of Zeus would have been the best suited for promoting the most Hellenic aspects of his policy (this proposal is formulated with extreme cautious since the sources presenting the king under this light were extremely hostile to his person). I would like to thank Cathy Lorber who brought my attention to the question of Antiochos' Zeus as image of the "Hellenizing" policy of the king (even if she doesn't agree with the possible and hypothetical connection drawn in this note between the god and the Hellenizing policy of the king).

39 Barbantani 2010, 236-237; 2014, 21-91.

40 See a similar analysis of Antiochos' III policy in Coloru 2017, 309-311. 
military operations opposing the Seleucid to the Ptolemies. The king's decision as translated through the qualitative and quantitative analysis of his Antiochene coinage argues in favor of a separation between the occidental and the oriental part of his kingdom: a particular interest for the West was articulated around the production of Antioch with its voluminous, new type issues destined to counterbalance the Ptolemaic propaganda presenting the Seleucids as heirs of the Achaemenids. On the eastern part, much less interesting for the king's policy (at least before he met his untimely death there in 164), Seleucia on the Tigris was downgraded to a regional level mint continuing the traditional Apollo seated on the omphalos typology; its coins circulated regionally and the area of Mesopotamia was dominated by the introduction of issues from the West.

The coins the king produced in abundance bearing his "divine" portrait, especially in the West, served the same purpose: declare the divine favor (eunoia) the king enjoyed because of his piety (eusebeia). The SHD analysis shows that these coins were produced and circulated mainly in the West and were destined to be used as tools for the legitimization of the king's position and overseas claims to the Egyptian throne. In a recent article, I argued that the bronze production of the king corroborates this scheme and connection with war efforts (especially with garrison duties), while in another article I demonstrated that his "divine" coins were an ideal tool for claiming the divine eunoia. ${ }^{41}$ Judging from the result of his reign, we can say that his numismatic program however successful might have been was doomed to fail because of military failure and/or Roman interference. On the other hand, if we consider the posterity of his innovations in Seleucid numismatics, we must admit that he created a new long lasting trend for his successors seeking to legitimize their power focusing on the role of Zeus as their patron deity. To the answer "tool of diplomacy or legitimacy," Antiochos' coinage created a new and successful model for the latter.

BIBLIOGRAPHY

Barbantani, S. (2010), Idéologie royale et littérature de cour dans l'Égypte lagide, in: I. Savalli-Lestrade, I. Cogitore (eds.), Des Rois au Prince. Pratiques du pouvoir monarchique dans l'Orient hellénistique et romain (IVe siècle avant J.-C.-II' siècle après J.C.), Grenoble: 227-251.

Barbantani, S. (2014), 'Attica in Syria': Persian Wars Reenactments and Reassessments of the GreekAsian Relationship: A Literary Point of View, Erga-Logoi 2/1: 21-91.

Capdetrey, L. (2007), Le pouvoir séleucide: Territoire, administration, finances d'un royaume hellénistique (312-129 av. J.-C.), Rennes.

Clancier, P. (2014), Antiochos IV dans les sources babyloniennes, in: L. Graslin, C. Feyel (eds.), Le projet politique d'Antiochos IV, Nancy: 353-376.

Coloru, O. (2014), Antiochos IV et le royaume de Médie Atropatène : nouvelles considérations sur un mariage dynastique entre les Séleucides et la maison d'Atropatès, in: C. Feyel, L. Graslin-Thomé (eds.), Le projet politique d'Antiochos IV, Nancy: 395-414.

${ }^{41}$ Iossif, 2016; 2018. 
Coloru, O. (2017), La forme de l'eau : idéologie, politique et stratégie dans l'Anabase d'Antiochos III, in: C. Feyel, L. Graslin-Thomé (eds.), Antiochos III et l'Orient, Nancy: 299-314.

Esty, W.W. (2006), How to Estimate the Original Number of Dies and the Coverage of a Sample, NC 166: 359-364.

Hoover, O.D. (2002), Laodice IV on the Bronze Coinages of Seleucus IV and Antiochus IV, AJN 14: $81-87$.

Houghton, A., Lorber, C.C., Hoover, O.D. (2008), Seleucid Coins: A Comprehensive Catalogue, part II, 2 vols., New York-Lancaster.

Iossif, P.P. (2011a), Seleucid Religion Through Coins: Is It Possible to Quantify 'Iconography' and 'Religion'?, in: F. de Callataÿ (ed.), Quantifying Monetary Supplies in Greco-Roman Times, Bari: 213-249.

Iossif, P.P. (2011b), Apollo Toxotes and the Seleukids: comme un air de famille, in: P.P. Iossif, A.S. Chankowski, C.C. Lorder (eds.), More than Men, Less than Gods: Studies in Royal Cult and Emperor Worship. Proceedings of the International Conference Organized by the Belgian School (Athens, 1-2 November 2007), Leuven-Paris-Dudley (MA): 229-291.

Iossif, P.P. (2012), Les 'cornes' des Séleucides : vers une divinisation « discrète », in: F. Duyrat, A. Suspène (eds.), Le Charaktèr du Prince, Actes du colloque organisé à Orléans, 15 octobre 2010, CEA 49: $45-150$.

Iossif, P.P. (2014), Seleucia on the Tigris under the Seleucids: 'Monetary' Pantheon vs. 'Glyptic' Pantheon, Mythos 7: 46-73.

Iossif, P.P. (2015), Who's Wealthier? An Estimation of the Annual Coin Production of the Seleucids and the Ptolemies, RBN 161: 233-272.

Iossif, P.P. (2016), Using Site Finds as Basis for Statistical Analyses of the Seleucid Numismatic Production and Circulation: An Introduction to the Method, in: F. Duyrat, C. Grandjean (eds), Les monnaies de fouille du monde grec (VI $-I^{e r}$ s. a.C.). Apports, approches et méthodes, Bordeaux: 263-296.

Iossif, P.P. (2017), Antiochos' III Precious Metal Numismatic Production seen through Hoard Data: A Quantitative Perspective, in: L. Graslin, C. Feyel (eds.), Antiochos III et l'Orient, Nancy: 37-76.

Iossif, P.P. (2018), Divine Attributes on Hellenistic Coinages: From noble to humble and Back, in: P.P. Iosif, F. de Callatä̈, R. Veymiers (eds.), TYПOI. Greek and Roman Coins Seen Through Their Images. Noble Issuers, Humble Users?, Proceedings of the International Conference Organized by the Belgian and French Schools at Athens, 26-28 September 2012, Liège: 269-295.

Iossif, P.P., Lorber, C. (2007), Marduk and the Lion: A Hoard of Babylonian Lion Staters, in: G. Moucharte et al. (eds.), Liber Amicorum Tony Hackens, Louvain-la-Neuve: 345-363.

Le Rider, G. (1999), Antioche de Syrie sous les Séleucides. I : De Séleucos I à Antiochos V, Paris.

Mittag, P.F. (2006), Antiochos IV. Epiphanes: Eine politische Biographie, Berlin.

Mørkholm, O. (1963), Studies in the Coinage of Antiochus IV of Syria, Copenhagen.

Mørkholm O. (1965/1966), Antiochos IV of Syria, Gyldendal.

Voulgaridis, G. (2000), Les ateliers monétaires de Ptolémaïs- 'Akko et d'Ascalon sous la domination séleucide, unpublished $\mathrm{PhD}$ thesis, University of Strasbourg. 


\section{Annex 1}

Hoards in SHD with coins of Antiochos IV*

\begin{tabular}{|c|c|c|c|c|}
\hline Order & Hoard's Name & $\begin{array}{c}\text { \# of Tetra- } \\
\text { drachms }\end{array}$ & $\begin{array}{l}\text { \# of Silver } \\
\text { Fractions }\end{array}$ & \# of AEs \\
\hline 1 & Trabzon-Ordu 1970 (lot A) & 5 & 0 & 0 \\
\hline 2 & Trabzon-Ordu 1970 (lot B) & 6 & 0 & 0 \\
\hline 3 & "Early Seleucid bronze hoard" & 0 & 0 & 2 \\
\hline 4 & "Late Seleucid bronze hoard" & 0 & 0 & 3 \\
\hline 5 & Aleppo 1931 & 7 & 0 & 0 \\
\hline 6 & Apamea 1996 & 17 & 0 & 0 \\
\hline 7 & Ascalon 1988 & 0 & 0 & 1 \\
\hline 8 & Babylone 1900 & 3 & 0 & 0 \\
\hline 9 & Bagdad 1954 & 31 & 0 & 0 \\
\hline 10 & Barda around 1929 & 1 & 0 & 0 \\
\hline 11 & Commerce 2001 & 0 & 4 & 0 \\
\hline 12 & Commerce 2002, "Hoard Demetrios I" A & 51 & 0 & 0 \\
\hline 13 & Commerce 2002, "Hoard de Demetrios I" B & 1 & 0 & 0 \\
\hline 14 & Commerce 2005, “Hoard Antiochos VII” & 1 & 0 & 0 \\
\hline 15 & Doura Europos 1933-1934 & 0 & 0 & 3 \\
\hline 16 & Hamadan 1977 & 4 & 103 & $\mathbf{0}$ \\
\hline 17 & Iran 1970 & 0 & 0 & 3 \\
\hline 18 & Judaea 2000 & 0 & 0 & 16 \\
\hline 19 & Kabala 1966 & 16 & 0 & 0 \\
\hline 20 & Kabala, Azerbaidjan (ancient Albania) & 18 & 0 & 0 \\
\hline 21 & Kessab 1947 & 0 & 0 & 1 \\
\hline 22 & Kishon river 1958 & 0 & 0 & 100 \\
\hline 23 & Lattakia 1759 & 6 & 0 & 0 \\
\hline 24 & Lebanon 1997 & 0 & 1 & 0 \\
\hline 25 & Ma'aret en Numan 1980 & 81 & 6 & $\mathbf{0}$ \\
\hline 26 & Mesopotamia 1953 & 1 & 0 & 0 \\
\hline 27 & N. Israel 2002 & 0 & 0 & 155 \\
\hline 28 & N. Syria or Cilicia Pedias 1994 & 27 & 0 & 0 \\
\hline 29 & Near East 1977 & 1 & 0 & 0 \\
\hline 30 & Nisibis 1955 & 0 & 0 & 3 \\
\hline 31 & Pamphylia or Cilicia 2000 & 3 & 0 & 0 \\
\hline 32 & Persis 1932-1933 & 0 & 14 & 0 \\
\hline
\end{tabular}




\begin{tabular}{|c|c|c|c|c|}
\hline Order & Hoard's Name & $\begin{array}{c}\text { \# of Tetra- } \\
\text { drachms }\end{array}$ & $\begin{array}{c}\text { \# of Silver } \\
\text { Fractions }\end{array}$ & \# of AEs \\
\hline $\mathbf{3 3}$ & Susa 1933-1934 & $\mathbf{8}$ & $\mathbf{1}$ & $\mathbf{0}$ \\
\hline 34 & Susa 1947-1948 & 0 & 2 & 0 \\
\hline 35 & Susa 1951-1952 & 0 & 1 & 0 \\
\hline 36 & Susiana 1958-1959 & 22 & 0 & 0 \\
\hline $\mathbf{3 7}$ & Susiana 1965 ? & $\mathbf{4 8}$ & $\mathbf{1}$ & $\mathbf{0}$ \\
\hline 38 & Syria 1971[iv] & 8 & 0 & 0 \\
\hline 39 & Syria 1990 & 30 & 0 & 0 \\
\hline 40 & Syria? before 1917 & 8 & 0 & 0 \\
\hline 41 & Without provenance, 2004 & $\mathbf{4 0 5}$ & $\mathbf{1 3 3}$ & $\mathbf{2 8 7}$ \\
\hline & Total & & & \\
\hline
\end{tabular}

* In bold are marked the mixt hoards. 